\title{
A Systematic Literature Review on Teaching and Learning English Using Mobile Technology
}

\author{
Siti Julia Mohd Shahrol, Shahida Sulaiman, Mohd Razak Samingan, and Hasnah Mohamed
}

\begin{abstract}
Mobile technology has become increasingly popular in the past decade and provides a chance to move forward towards $21^{\text {st }}$ century education. The art of teaching and learning English with the adoption of mobile technology creates a different learning environment for both teachers and students. Hence, reviewing existing works systematically is crucial in finding the gaps in teaching and learning English using mobile technology. A Systematic Literature Review (SLR) is conducted to identify important factors influenced in the teaching and learning English using mobile technology and existing studies in overcoming the issues. The results show that providing suitable educational technology is one of the key success factors to enhance teaching and learning English. This paper reports the key gap and limitation in current studies that focus on teaching and learning English using mobile technology.
\end{abstract}

Index Terms-Systematic literature review, mobile technology, teaching and learning, English, 21st century education, education 4.0.

\section{INTRODUCTION}

Global connectivity, smart machine and new media are some drivers in Industry 4.0. Society adapted to be more social, more knowledgeable and world become smaller than before because of the pervasive nature of the Internet in the fourth industrial revolution [1]. Hence, Education 4.0 is a response to the needs of Industry 4.0, where human and machine coordinate together to create new possibilities in the new education [2]. Learning skills in Education 4.0 need to combine life skills and innovative skills with a combination of 21st-century skills which are leadership, collaboration, creative, digital literacy, effective communication, emotional intelligence, entrepreneurship, global citizen, problem-solving and teamwork [3]. A combination of adopting these skills is the key element to encourage learners to use intelligent agents, mobile technologies and cloud computing to promote interactive education.

With the advancement of technologies, the education field has integrated mobile technologies as an educational tool that can be used within and beyond the classroom [4]. The adoption of mobile technology creates an interactive learning environment by making learning contents using videos and

Manuscript received February 5, 2020; revised May 3, 2020. This work is supported by South East Johor Development Authority (KEJORA) under the Cost Centre 4B349, Centre for Advancement in Rural Education Informatics, Universiti Teknologi Malaysia (UTM), Malaysia.

S. J. M. Shahrol, S. Sulaiman and M. R. Samingan are with School of Computing, Faculty of Engineering, Universiti Teknologi Malaysia, 81310 Johor Bahru, Johor, Malaysia (e-mail: sjshahrol@gmail.com, shahidasulaiman@utm.my,mrazak@utm.my).

H. Mohamed is with School of Education, Faculty of Social Science and Humanities, Universiti Teknologi Malaysia, 81310 Johor Bahru, Johor, Malaysia (e-mail: hasnah-m@utm.my). multimedia formats available through mobile devices such as tablets, handheld devices or smartphones [5]. Thus, this technology can make the learning process more students centred, meaningful and able to encourage students to explore their creativity and encourage innovation by both teachers and learners.

Nowadays, mobile technology becomes essential for most educators and learners. The latest evolution of mobile technology leads to a challenging environment for educators, technology developers and learners on how to perceive and adopt this technology to access learning materials, the content of learning and establishing communication between educators and learners [6]. This slowly changes from teacher-based instruction to modern technology-based learning where it has changed from a traditional textbook to interactive and captivating apps, from boring classroom to smart classroom and from silent learners to active learners. By using this technology, it helps to create a better environment for the learning process.

Most of the learners today are from Millennial Generation as known as digital natives, those born in 1982 or later. The most impressive characteristic of these learners is they have been raised and get exposed to technology since born. In general, they need an alternative method of teaching and learning to ensure they actively engaged in the learning process as well as creating satisfaction in a learning environment [7]. Consequently, teachers or educators that use technology in teaching and learning indirectly will motivate the learners and will produce effective learning outcome as technology playing a big role in their learning area.

The objectives of this paper are to identify factors concerning teaching and learning English using mobile technology, to summarize the existing works towards improving teaching and learning English using mobile technology and to identify strengths and limitations of the current solutions in teaching and learning English using mobile technology. The studies in existing works on teaching and learning English using mobile technology still lack a systematic method. Thus, this paper reports a systematic review of existing works within the scope of the study.

This paper contains four sections. Section 2 provides the details of the review process while Section 3 presents the research results and discussion. Lastly, Section 4 concludes the study and recommends future work.

\section{REVIEW PROCESS}

A Systematic Literature Review (SLR) identifies, evaluates, interprets and analyses the available research findings related to formulated research questions, topic area 
or phenomenon. The main purpose of conducting a systematic review is to construct a general vision, gather evidence of specific questions and give a summary of the literature. This study conducted the SLR based on the guidelines by Kitchenham and Charters [8] to identify, evaluate, interpret and analyse available study to address specific research questions on the effectiveness of mobile technology to support teaching and learning the English language.

This study contains four steps, which are formulation of a focused review question, a comprehensive and thorough search of primary studies, identifying inclusion and exclusion criteria and assessment of the quality of the included study. The explanation for each step is indicated in the following sub-sections.

\section{A. Research Questions}

To identify research questions for the SLR, there are several numbers of criteria to be considered before conducting the SLR process which are population, intervention, comparison and outcomes as in Table I.

\section{TABLE I: CRITERIA AND ITS SCOPE}

\begin{tabular}{ll}
\hline \hline Criteria & Scope \\
\hline Population & $\begin{array}{l}\text { Papers that propose a technique/ approach/model/ } \\
\text { framework in teaching and learning English using } \\
\text { mobile technology. }\end{array}$ \\
Entervention & $\begin{array}{l}\text { Existing works that address factors in teaching and } \\
\text { learning English and proposed work using mobile } \\
\text { technology. }\end{array}$ \\
Comparison & $\begin{array}{l}\text { Strengths and limitations of each proposed work using } \\
\text { mobile technology in teaching and learning English. }\end{array}$ \\
Outcomes & $\begin{array}{l}\text { Factors in teaching and learning English using mobile } \\
\text { technology and proposed work that used to overcome } \\
\text { the issues. }\end{array}$ \\
\hline \hline
\end{tabular}

Based on the research questions structure, the detailed research questions are as follow:

RQ1: What are the important factors concerning in teaching and learning English using mobile technology?

RQ2: What are the current solutions that support teaching and learning English using mobile technology?

RQ3: What are the strengths and limitations of the existing works?

\section{B. Search Process}

This study uses the iterative search process that consists of the following steps.

1) Initial search in online database library: Used Mendeley

Desktop with keywords in Table II such as "Factors using mobile technology in teaching and learning" and "Model/ approach/ techniques/ framework in teaching and learning English using mobile technology".

2) Refine search in major indexing databases: The major indexing database libraries referred to IEEE Xplore Digital Library, ScienceDirect, SpringerLink and ACM Digital Library.

3) Record search result

4) Classify and catalogue the academic papers according to types of publications: Works were organised based on type including journals, conference, book chapters, theses, technical books, technical magazines reports, Web pages and guidelines.
TABLE II: SEARCH KEYWORD CODE

\begin{tabular}{ll}
\hline \hline Keyword Code & Detailed Keywords \\
K1 & $\begin{array}{l}\text { Factors using mobile technology in teaching and } \\
\text { learning }\end{array}$ \\
K2 & $\begin{array}{l}\text { Issues in teaching and learning English } \\
\text { Model/ approach/ techniques/ framework in } \\
\text { teaching and learning English using mobile } \\
\text { K3 }\end{array}$ \\
technology \\
Mobile technology in teaching and learning English
\end{tabular}

\section{Inclusion and Exclusion Criteria}

To conduct a systematic literature review, some inclusion criteria are considered. Firstly, a collection of paper was reviewed and sorted from the source library and priority is given to published papers from journals and conferences. Thus, the papers must be written in English. Hence, the papers should at least contain factors concerning teaching and learning English and the field of study must be related to the Computer Science field, Software Engineering field, Educational Technologies and Computers and Education. Based on the search process, the papers were required to include keywords that attempt to define, propose, suggest or describe existing works in teaching and learning English using mobile technology.

There are also exclusion criteria applied to the SLR. Papers that not written in English or other languages automatically were excluded from this SLR. Papers that do not follow the listed keywords, even though from a related field, were excluded. Lastly, the papers that fulfilled inclusion and exclusion criteria were short-listed and reviewed for final selection.

\section{Quality Evaluation}

To validate the quality of the selected articles, a few questions have been developed as a guideline to select relevant articles for this study. This phase is vital to ensure that only relevant, valid and related articles to the study were selected and applied to comply with quality assessment. Articles will be included based on the evaluation as below:

- Clearly discussing factors concerning teaching and learning English using mobile technology,

- Clearly defining model/ approach/ framework and/or

- Discussing the strengths and limitations of the proposed works.

Thus, for the articles that partially engaged the evaluation process, the search process was clarified to retrieve relevant and appropriate information to fulfil the quality evaluation; otherwise, the article will be excluded. This process on the selected paper is important to gain the accuracy of the data extraction results. Table III depicts the questions used in the article's selection process.

\section{TABLE III: RESEARCH QUESTION STRUCTURE}

\begin{tabular}{ll}
\hline \hline Question & Answer \\
\hline $\begin{array}{l}\text { Do the articles report important factors } \\
\text { concerning teaching and learning English using } \\
\text { mobile technology? }\end{array}$ & (Yes/No/Partially) \\
$\begin{array}{l}\text { Do the articles propose any } \\
\text { approach/model/framework in teaching and }\end{array}$ & (Yes/No/Partially) \\
learning using mobile technology? & \\
$\begin{array}{l}\text { Do the articles compare the strengths and } \\
\text { limitations of existing works? }\end{array}$ & (Yes/No/Partially) \\
\hline \hline
\end{tabular}




\section{RESUlt AND DisCUSSION}

The outcome of the SLR leads to the exploration of teaching and learning English using mobile technology. The 51 selected papers met the criteria following the steps in the search process as shown in Table IV.

TABLE IV: SEARCH PROCESS AND KEYWORDS

\begin{tabular}{lcccc}
\hline \multirow{2}{*}{ Search Process } & \multicolumn{4}{c}{ Keyword } \\
\cline { 2 - 5 } & $\mathrm{K} 1$ & $\mathrm{~K} 2$ & $\mathrm{~K} 3$ & K4 \\
\hline Initial & 40 & 194 & 72 & 299 \\
Refine & 22 & 63 & 50 & 30 \\
Exclude & 18 & 48 & 30 & 16 \\
Include & 11 & 15 & 11 & 14 \\
\hline \hline
\end{tabular}

The discussion will be based on the SLR research questions as in the following subsections.

\section{A. Teaching and Learning English Using Mobile Technology}

The first research question is: Do the articles report important factors concerning teaching and learning English using mobile technology? From the reviewed studies, there is a number of factors concerning teaching and learning English were identified. Table $\mathrm{V}$ shows some factors concerning teaching and learning English using mobile technology.

TABLE V: FACTORS CONCERNING TEACHING AND LEARNING ENGLISH USING MOBILE TECHNOLOGY

\begin{tabular}{|c|c|}
\hline Factors & Articles \\
\hline Social influence & [9], [10] \\
\hline Motivation & [11]-[13] \\
\hline Interactive teaching materials and activities & {$[13],[14]$} \\
\hline Teachers' and students' readiness and perception & {$[5],[13],[15]-[17]$} \\
\hline
\end{tabular}

Social influence is one of the factors that influence learners' intention to use mobile technology in learning English [9]. This factor including teachers and peers that also affect students' behaviour during the learning process using such technology [10].

Thus, motivation factor leads to the integration of mobile technology in teaching and learning for both educators and learners. The adopting of mobile technology as an educational tool can affect learning process as well as raise students' motivation towards the learning process [11]-[13].

Additionally, providing students with suitable and interesting teaching material that are presented digitally lead to students' perception to positively adapt the use of mobile technology to support language learning [13]. In order to create an interactive technology-based learning environment, the integration of mobile technology in classrooms can be applied for both teachers and learners [14].

Some studies state that teachers' and students' readiness including perception are among the important factors that drive the adoption of mobile technology in teaching and learning English. Within the educational sector, teachers' and students' readiness is directly integrated with mobile self-efficacy. Teachers agree that using mobile technology during learning process increase their teaching proficiency and enhance their quality of teaching [5]. By using mobile technology and mobile applications, teachers' and students' perception causes change from traditional verbal instruction to communication through mobile devices at any time and any place [13]. Regarding teachers' and students' readiness and perception, it is vital to put forward the role of administrators to give support and encouragement to create awareness and readiness for the teachers and students to update their technological skill [15]. Teachers' and students' readiness and perception also lead the students to actively participate, engage and concentrate during the learning activities [16]. Calabrich [17] reports that learners' perception was in overall positive as mobile devices allowed them to get visual scaffolding, search information and learning material online. Additionally, the level of acceptance of tasks given by the teachers was surprisingly high as students felt confident to complete the task using the features in mobile technology.

\section{B. Existing Proposed Works}

The second research question is: Do the articles propose any approach/model/framework in teaching and learning English using mobile technology? From the result obtained in the SLR study, the proposed work by each article is also recorded. Table VI shows the results of the model, approach or framework proposed by each article. Most of the works related to teaching and learning English using mobile technology mentioned model, frameworks or approaches.

TABLE VI: EXISTING PROPOSED WORKS

\begin{tabular}{|c|c|c|}
\hline \multicolumn{2}{|c|}{ Category } & \multirow{2}{*}{$\begin{array}{l}\text { Point of Discussion } \\
\text { Using interactive activities in } \\
\text { Socrative for teaching and } \\
\text { learning }\end{array}$} \\
\hline \multirow{3}{*}{$\frac{\bar{d}}{\sum_{0}^{\circ}}$} & $\begin{array}{l}\text { Mobile-Based Interactive } \\
\text { Teaching Model Using } \\
\text { Socrative [13] }\end{array}$ & \\
\hline & $\begin{array}{l}\text { Problem Based Learning } \\
\text { (PBL) Strategy [16] }\end{array}$ & $\begin{array}{l}\text { Using mobile devices to help } \\
\text { students solve the problem or task }\end{array}$ \\
\hline & $\begin{array}{l}\text { Mobile-Assisted Teaching } \\
\text { Model [18] }\end{array}$ & $\begin{array}{l}\text { Establish a teaching model by } \\
\text { using LINE mobile app to assist } \\
\text { teaching and learning English }\end{array}$ \\
\hline \multirow{2}{*}{ 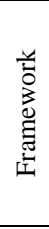 } & $\begin{array}{l}\text { The Framework for the } \\
\text { Rational Analysis of Mobile } \\
\text { Education (FRAME) [19] }\end{array}$ & $\begin{array}{l}\text { Discuss three components of } \\
\text { mobile learning consist of device, } \\
\text { learner and social }\end{array}$ \\
\hline & $\begin{array}{l}\text { Technological Pedagogical } \\
\text { and Content Knowledge } \\
\text { (TPACK) }[20]\end{array}$ & $\begin{array}{l}\text { Create a learning environment } \\
\text { with a combination of } \\
\text { technology, pedagogical and } \\
\text { content knowledge }\end{array}$ \\
\hline \multirow{4}{*}{ 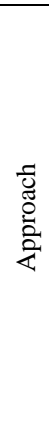 } & $\begin{array}{l}\text { Mobile Pedagogy Approach } \\
\text { [21] }\end{array}$ & $\begin{array}{l}\text { Emphasize the role of the teacher } \\
\text { while adopting technology in the } \\
\text { learning process }\end{array}$ \\
\hline & $\begin{array}{l}\text { Mobile Collaborative } \\
\text { Learning Using Tablet [22] }\end{array}$ & $\begin{array}{l}\text { Discussed learning impact with } \\
\text { mobile tablets in individual and } \\
\text { group setting }\end{array}$ \\
\hline & $\begin{array}{l}\text { Situated Learning with } \\
\text { Scaffolding Strategy using } \\
\text { AR [23] }\end{array}$ & $\begin{array}{l}\text { Used Augmented Reality (AR) } \\
\text { object to engage learners to } \\
\text { understand learning }\end{array}$ \\
\hline & $\begin{array}{l}\text { Mobile Game-Based } \\
\text { Learning with a Mobile App } \\
{[24]}\end{array}$ & $\begin{array}{l}\text { Discussed on how mobile } \\
\text { application influence learning } \\
\text { performance and motivational } \\
\text { effect }\end{array}$ \\
\hline \multirow{4}{*}{ 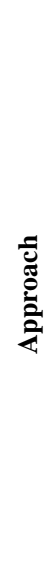 } & $\begin{array}{l}\text { Multimedia Enabled } \\
\text { Teaching and Learning } \\
\text { Process [25] }\end{array}$ & $\begin{array}{l}\text { Implementation of content } \\
\text { knowledge using multimedia to } \\
\text { increase students' motivation. }\end{array}$ \\
\hline & $\begin{array}{l}\text { Mobile Game Application in } \\
\text { Learning English Vocabulary } \\
{[26]}\end{array}$ & $\begin{array}{l}\text { Using mobile game application } \\
\text { (Vocab Game) to boost students' } \\
\text { motivation in learning English } \\
\text { language. }\end{array}$ \\
\hline & $\begin{array}{l}\text { Mobile Assisted Language } \\
\text { Learning [27] }\end{array}$ & $\begin{array}{l}\text { Investigate the implementation of } \\
\text { mobile technology in reading } \\
\text { activity using mobile features and } \\
\text { applications like camera, } \\
\text { dictionary, Whatsapp, notes and } \\
\text { website. }\end{array}$ \\
\hline & Educational Mobile App [28] & $\begin{array}{l}\text { Embodied Behaviorist learning } \\
\text { theory in the educational mobile } \\
\text { app that concerns reinforcement } \\
\text { in learning by giving stimulus and } \\
\text { response. }\end{array}$ \\
\hline
\end{tabular}




\section{Strengths and Limitations}

The third research question is: Do the articles compare the strengths and limitations of existing works? Table VII shows the strengths and limitations for each existing work and the overall discussions show that the current works improve teaching and learning English by adopting mobile technology. For example, the implementation of mobile game-based learning influence learning performance and motivational effect. The ability of few models that combine three components which are device, learner and social provide an impulsive way to create learning activities

However, there are some weaknesses in the current work that can be refined to fulfil current and future teachers' and students' needs to achieve learning objectives. Some weaknesses include using mobile technology may distract the students to stay focus, some educational applications cannot be used without the Internet connection and teacher, and each current works need teachers' cooperation to create an interesting environment for learning.

TABLE VII: STRENGTHS AND LIMITATION OF EXISTING WORKS

\begin{tabular}{|c|c|c|c|}
\hline \multicolumn{2}{|c|}{ Category } & \multirow{2}{*}{$\begin{array}{l}\text { Strengths } \\
\text { Allows teachers to engage and assess students' performance } \\
\text { through educational activities using mobile technology. }\end{array}$} & \multirow{2}{*}{$\begin{array}{l}\text { Limitations } \\
\text { Teacher needs to connect to the internet to } \\
\text { access the report from the educational } \\
\text { application. }\end{array}$} \\
\hline \multirow{3}{*}{ 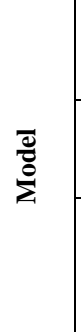 } & $\begin{array}{l}\text { Mobile-Based Interactive } \\
\text { Teaching Model Using } \\
\text { Socrative [13] }\end{array}$ & & \\
\hline & $\begin{array}{l}\text { Problem Based Learning (PBL) } \\
\text { Strategy [16] }\end{array}$ & $\begin{array}{l}\text { Students played an active part in inquiry activities and used } \\
\text { mobile devices to find information. }\end{array}$ & $\begin{array}{l}\text { Some students marked that PBL takes too much } \\
\text { time to complete the task would misuse the } \\
\text { mobile device to do something else. }\end{array}$ \\
\hline & $\begin{array}{l}\text { Mobile-Assisted Language } \\
\text { Teaching Model [18] }\end{array}$ & $\begin{array}{l}\text { Learners generates improvement in their English language } \\
\text { performance in public speaking class. Instructor could send } \\
\text { their learning material to the students after and before class by } \\
\text { using LINE app. }\end{array}$ & $\begin{array}{l}\text { Instructor felt that integrating this app is } \\
\text { time-consuming and requires a lot of effort if } \\
\text { the instructor not familiar with the app. }\end{array}$ \\
\hline \multirow{2}{*}{ 产 } & $\begin{array}{l}\text { The Framework for the Rational } \\
\text { Analysis of Mobile Education } \\
\text { (FRAME) [19] }\end{array}$ & $\begin{array}{l}\text { Facilitate the learning process with integrating mobile devices } \\
\text { in distance learning and deliver the content of knowledge, } \\
\text { learning activities and communication between teacher and } \\
\text { students used mobile devices. }\end{array}$ & $\begin{array}{l}\text { Students in a different location may feel } \\
\text { demotivated and they feel disconnected with } \\
\text { the learning process. }\end{array}$ \\
\hline & $\begin{array}{l}\text { Technological Pedagogical and } \\
\text { Content Knowledge (TPACK) } \\
\text { [20] }\end{array}$ & $\begin{array}{l}\text { Integration technology in the classroom creates an effective } \\
\text { and powerful learning process. Role of teacher is important to } \\
\text { appropriately select and use the technology and create } \\
\text { students-centred learning and low-structure situation as } \\
\text { students provided with teaching material. }\end{array}$ & $\begin{array}{l}\text { Teachers who are not trained to use the } \\
\text { technology will not adopt the technology in the } \\
\text { classroom. }\end{array}$ \\
\hline \multirow{4}{*}{ 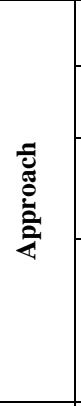 } & $\begin{array}{l}\text { Mobile Pedagogy Approach } \\
\text { [21] }\end{array}$ & $\begin{array}{l}\text { Help teachers to create their learning content using mobile } \\
\text { technology. }\end{array}$ & $\begin{array}{l}\text { This approach depends on the teacher to create } \\
\text { an interesting environment for learning. }\end{array}$ \\
\hline & $\begin{array}{l}\text { Mobile Collaborative Learning } \\
\text { Using Tablet [22] }\end{array}$ & $\begin{array}{l}\text { Encouraging active learning and learning occurs more } \\
\text { effectively when learners interact with their peers. }\end{array}$ & $\begin{array}{l}\text { Students focus may distract as they can do } \\
\text { another work using tablet. }\end{array}$ \\
\hline & $\begin{array}{l}\text { Situated Learning with } \\
\text { Scaffolding Strategy using AR } \\
\text { [23] }\end{array}$ & $\begin{array}{l}\text { Use an Augmented Reality (AR) object to help students } \\
\text { understand the learning content. Students' motivation raised } \\
\text { with the help of scaffolding. }\end{array}$ & $\begin{array}{l}\text { Students sometimes feel difficult to scan items } \\
\text { using the AR object due to light exposure. }\end{array}$ \\
\hline & $\begin{array}{l}\text { Mobile Game-Based Learning } \\
\text { with a Mobile App [24] }\end{array}$ & $\begin{array}{l}\text { Students installed the game into their smartphones and play } \\
\text { English vocabulary by playing the game. Using mobile } \\
\text { devices students boosting their confidence and gained higher } \\
\text { satisfaction. Hence, students create immerse learning } \\
\text { experience and encourage experiential learning. }\end{array}$ & $\begin{array}{l}\text { Learners' focus shift to winning the game and } \\
\text { shift students' focus from collaboration activity. } \\
\text { Diminishes the importance of cooperation and } \\
\text { sharing ideas. }\end{array}$ \\
\hline \multirow{4}{*}{ 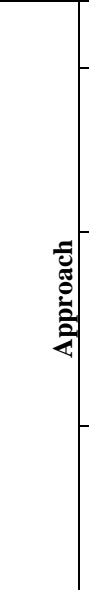 } & $\begin{array}{l}\text { Multimedia Enabl } \\
\text { and Learning Proc }\end{array}$ & $\begin{array}{l}\text { Multimedia content knowledge for learning can be shared and } \\
\text { accessed using smartphones. }\end{array}$ & $\begin{array}{l}\text { The content knowledge for this approach does } \\
\text { not include animation. }\end{array}$ \\
\hline & $\begin{array}{l}\text { Mobile Game Application in } \\
\text { Learning English Vocabulary } \\
\text { [26] }\end{array}$ & $\begin{array}{l}\text { Using VocabGame in learning vocabulary increased students' } \\
\text { motivation and they showed good performance in general. }\end{array}$ & $\begin{array}{l}\text { Insufficient mobile devices during the } \\
\text { implementation reduce the training time and } \\
\text { lack of time for the students to use the mobile } \\
\text { game application due to school constraints and } \\
\text { limitations. }\end{array}$ \\
\hline & $\begin{array}{l}\text { Mobile Assisted Language } \\
\text { Learning [27] }\end{array}$ & $\begin{array}{l}\text { Students are more independent during reading activity by } \\
\text { integrating mobile features and applications. The students } \\
\text { effectively engaged and participate during the learning } \\
\text { activities as well as teachers could save time. The mobile } \\
\text { features and applications intervened to scrutinize reading } \\
\text { practices. }\end{array}$ & $\begin{array}{l}\text { This approach only focuses on reading } \\
\text { activities. It was a challenge to sustain the } \\
\text { students focus, determination and motivation to } \\
\text { keep going learning outside the classroom by } \\
\text { posting irrelevant questions and comments. }\end{array}$ \\
\hline & Educational Mobile App [28] & $\begin{array}{l}\text { Educational mobile app could facilitate teaching and learning } \\
\text { English literature using Shakespeare app inside and outside } \\
\text { classroom in innovative way. Learners experienced } \\
\text { game-learning so learners could learn literature in from } \\
\text { multiple dimensions. }\end{array}$ & $\begin{array}{l}\text { Although this approach could facilitate teaching } \\
\text { and learning, games could lead to students' } \\
\text { addiction and teachers who not familiar with the } \\
\text { technology would have problem. }\end{array}$ \\
\hline
\end{tabular}

\section{CONCLUSION AND FUtURE WORK}

The future of using mobile technology in language education is promising and the features provided in mobile applications are captivating. This paper reports a SLR of the selected articles based on the three research questions regarding teaching and learning English using mobile technology. The results from the study deduce some issues that require some improvements in teaching and learning English using mobile technology. The study concludes that mobile technology has a significant impact on academic performance to motivate and engage the students and allow the students to benefit the quality of learning process. Future works will be to eliminate the gaps in the existing solutions and to design a model to support teaching and learning English using mobile technology in line with 21 st century 
education to meet the needs of Education 4.0.

\section{CONFLICT OF INTEREST}

The authors declare no conflict of interest.

\section{AUTHOR CONTRIBUTIONS}

The first author conducted the research and wrote the research paper. The second author revisited the SLR method, reviewed and revised the whole paper accordingly. The third author gave the input in the technical aspects, while the fourth author contributed in educational perspectives. All authors had approved the final version.

\section{ACKNOWLEDGMENT}

S. J. M. Shahrol acknowledges South East Johor Development Authority (KEJORA) for the scholarship that supports this research for her PhD work and Cost Centre 4B349, Centre for Advancement in Rural Education Informatics (iCARE) community project that provides the platform for the community-based participatory research.

\section{REFERENCES}

[1] F. Griffiths and M. Ooi, "The fourth industrial revolution - Industry 4.0 and IoT [Trends in Future I and M]," IEEE Instrumentation and Measurement Magazine, vol. 21, pp. 29-43, 2018.

[2] A. A. Shahroom and N. Hussin, "Industrial revolution 4.0 and education," International Journal of Academic Research in Business and Social Sciences, vol. 8, pp. 314-319, Oct. 2018.

[3] V. Puncreobutr, "Education 4.0: New challenge of learning," Humanitarian and Socio-Economic Sciences, vol. 2, pp. 92-97, July 2016.

[4] S. M. Leahy, C. Holland, and F. Ward, "The digital frontier: Envisioning future technologies impact on the classroom," Futures, vol. 113, pp. 1-10, April 2019.

[5] J. O. Osakwe, M. Ujakpa, G. Iyawa, and K. Florich, "Enabling quality education in Namibia through mobile learning technologies. The high school teachers' perspective," in Proc. IST-Africa Week Conference (IST-Africa), 2018, pp. 1-9.

[6] E. Garcia, I. Elbeltagi, and M. Bugliolo, "Introducing 4G mobile networks: Implications for UK higher education," in Proc. 2019 International Journal of Info and Learning Tech, vol. 32, 2015, pp. 124-135.

[7] M. Prenksy, "Digital natives, digital immigrants," On the Horizon, vol. 9 , pp. 1-6, Oct. 2001

[8] B. Kitchenham and S. Charters, Guidelines for Performing Systematic Literature Reviews in Software Engineering, Technical Report EBSE 2007-001, Keele University and Durham University Joint Report, 2007.

[9] L. Briz-Ponce, A. Pereira, L. Carvalho, J. A. Juanes-Méndez, and F. J. García-Peñalvo, "Learning with mobile technologies - Students' behaviour," Computers in Human Behavior, vol. 72, pp. 612-620, July 2017.

[10] H. Hashim, M. M. Yunus, and M. A. Embi, "Factors influencing polytechnic English as second language (ESL) learners' attitude and intention for using mobile learning," Asian ESP Journal, vol. 14, pp. 195-208, Dec. 2018.

[11] A. J. Martin, M. Mansour, and L. E. Malmberg, "What factors influence students' real-time motivation and engagement? An experience sampling study of high school students using mobile technology," Educational Psychology, Feb. 2019.

[12] K. F. Hashim, F. B. Tan, and A. Rashid, "Adult learners' intention to adopt mobile learning: A motivational perspective," British Journal of Educational Technology, vol. 46, pp. 381-390, March 2015.

[13] H. Hamidi and A. Chavoshi, "Analysis of the essential factors for the adoption of mobile learning in higher education: A case study of students of the University of Technology," Telematics and Informatics, vol. 35, pp. 1053-1070, July 2018.

[14] W. N. Lim, "Improving student engagement in higher education through mobile-based interactive teaching model using Socrative," in Proc. IEEE Global Engineering Education Conference, EDUCON, April 2017, pp. 404-412.
[15] N. Salem and B. Mohammadzadeh, "A study on the integration of ICT by EFL teachers in Libya," Eurasia Journal of Mathematics, Science and Technology Education, vol. 14, pp. 2787-2801, April 2018.

[16] Z. Chen et al., "A PBL teaching model based on mobile devices to improve primary school students' meta-cognitive awareness and learning achievement," in Proc. 6th International Conference of Educational Innovation through Technology, 2018, pp. 81-86.

[17] S. L. Calabrich, "Learners' perceptions of the use of mobile technology in a task-based language teaching experience," International Education Studies, vol. 9, pp. 120-136, July 2016

[18] R. Shih, C. Papa, and T. Cheng, "Establishment of a mobile-assisted language teaching model for english teachers of technological universities and colleges," in Proc. 2013 Second International Conference on Robot, Vision and Signal Processing, 2013, pp. 144-147.

[19] M. L. Koole, "Mobile learning - A model for framing mobile learning," Mobile Learning: Transforming the Delivery of Education and Training, vol. 1, pp. 25-47, March 2009.

[20] J. Harris, M. Koehler, M. J. Koehler, and P. Mishra., "What is technological pedagogical content knowledge?" Contemporary Issues in Technology and Teacher Education, vol. 9, pp. 60-70, 2009.

[21] A. Kukulska-Hulme, L. Norris, and J. Donohue, Mobile Pedagogy for a Guide for Teachers, London, UK: British Council, 2015, pp. 7-21.

[22] I. Reychav and $\mathrm{D}$. Wu, "Computers in human behavior mobile collaborative learning: The role of individual learning in groups through text and video content delivery in tablets," Computers in Human Behavior, vol. 50, pp. 520-534, May 2015

[23] S. W. Chew, J. Y. Jhu, and N. S. Chen, "The effect of learning English idioms using scaffolding strategy through situated learning supported by augmented reality," in Proc. IEEE 18th International Conference on Advanced Learning Technologies, ICALT 2018, July 2018, pp. 390-394.

[24] Y. L. Huang, D. F. Chang, and B. Wu, "Mobile game-based learning with a mobile app: Motivational effects and learning performance," Journal of Advanced Computational Intelligence and Intelligent Informatics, vol. 21, pp. 963-970, Oct. 2017.

[25] M. Kemal, M. W. Ahmad, and A. Zewege, "Use of multimedia as a new educational technology tool for preparatory students (The case of goro preparatory school)," in Proc. 2016 2nd International Conference on Computational Intelligence and Communication Technology, CICT 2016, Feb. 2016, pp. 733-743.

[26] M. M. Elaish, N. A. Ghani, L. Shuib and A. Al-haiqi, "Development of a mobile game application to boost students' motivation in learning English vocabulary," IEEE Access, vol. 7, pp. 13326-13337, 2019.

[27] A. N. Hazaea and A. A. Alzubi, "The effectiveness of using mobile on EFL learners' reading practices in Najran University," English Language Teaching, vol. 9, pp. 8-21, 2016.

[28] A. Suen and A. Fung "Shakespeare in the apps: Mobile technology in education context," International Journal of Information and Education Technology, vol. 6, pp. 731-736, 2016.

Copyright (C) 2020 by the authors. This is an open access article distributed under the Creative Commons Attribution License which permits unrestricted use, distribution, and reproduction in any medium, provided the original work is properly cited (CC BY 4.0).

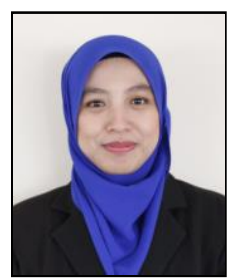

Siti Julia Mohd Shahrol was born in August, 1981 She was awarded a bachelor's degree of information technology in 2004 by Universiti Utara Malaysia. She is currently pursuing a master's degree in the School of Computing, Universiti Teknologi Malaysia under the supervision of Associate Professor Dr. Shahida Sulaiman and Senior Lecturer Dr. Hasnah Mohamed.

She receives the scholarship from South East Johor Development Authority (KEJORA) that supports this research under the Cost Centre 4B349, Centre for Advancement in Rural Education Informatics (iCARE) UTM-KEJORA that provides the platform to conduct a community-based participatory research. Her research interest include mobile technology, teaching and learning English, $21^{\text {st }}$ century education, Education 4.0 and systematic literature review.

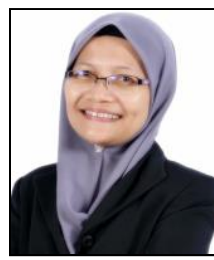

Shahida Sulaiman is an associate professor in the School of Computing, Faculty of Engineering, Universiti Teknologi Malaysia (UTM) since 2011 Formerly, she had served at Universiti Sains Malaysia (USM) for seven years. She received a M.Sc. degree in computer science - real time software engineering in 2000 and Ph.D. degree in computer science in 2004 from UTM, Malaysia. She is an IEEE member since 2013. She has published and co-authored numerous 
technical papers mainly in software engineering area, has been the editors for a number of journals, book chapters and conference proceedings, besides serving as reviewers and technical committee members mainly in IEEE conferences including Scopus and ISI indexed proceedings and journals in related fields. She founded a knowledge portal, syerilmu.com that has also been a platform for case studies related to software usability, software reliability, and requirements engineering among others. Her research interests include software design and architecture, software visualisation and evolution, knowledge management, and education informatics.

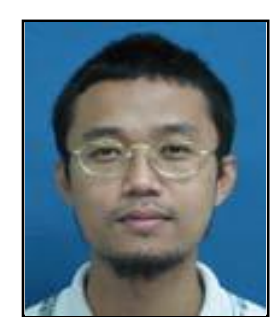

Mohd Razak Samingan is a lecturer in the Schoo of Computing, Faculty of Engineering, Universiti Teknologi Malaysia (UTM) since 2000. He received a M.Sc. degree in computer science distributed multimedia system in 1998 from University of Leeds, UK and Ph.D degree in computer science in 2017 from UTM, Malaysia. His research interests include web technology, software architecture and application framework. $\mathrm{He}$ is currently active in consultation for software development projects especially in the area of Web-based and mobile system for several industry partners in the state of Johor, Malaysia.

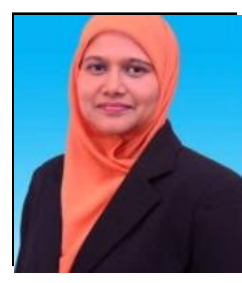

Hasnah Mohamed is a senior lecturer in the Schoo of Education, Faculty of Social Science and Humanities, Universiti Teknologi Malaysia (UTM) since 2013. Formerly, she had served as a secondary school teacher for 16 years. She received a M. Ed (education technology) degree in 2002 and Ph.D degree in educational technology in 2012 from UTM, Malaysia. She has published and co-authored numerous technical papers mainly in the education area, has been the editors for several journals, book chapters and conference proceedings, besides serving as reviewers and technical committee members of journals in the related fields. Her research interests include computer-assisted learning, computer-assisted instruction, flipped classroom, gamification and other education related research. 